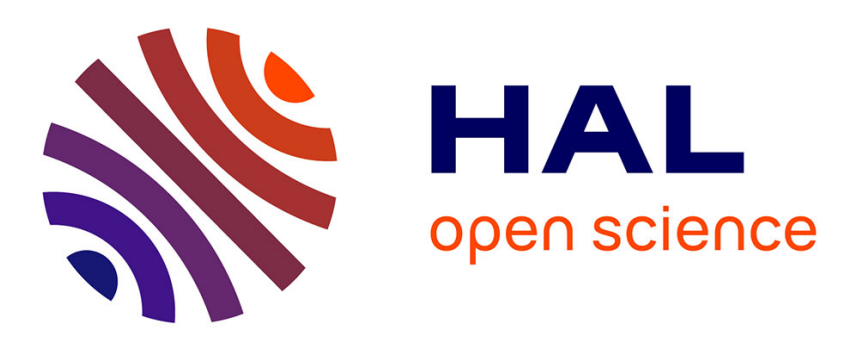

\title{
Relative fundamental Frequency of voiced and voiceless stops and fricatives for different phonation types in normal French speakers
}

Camille Robieux, Christine Meunier

\section{To cite this version:}

Camille Robieux, Christine Meunier. Relative fundamental Frequency of voiced and voiceless stops and fricatives for different phonation types in normal French speakers. 5th Joint Meeting of the Acoustical Society of America and Acoustical Society of Japan, Nov 2016, Honolulu, United States. , 2016, 5th Joint Meeting of the Acoustical Society of America and Acoustical Society of Japan. hal-01453113

\author{
HAL Id: hal-01453113 \\ https://hal.science/hal-01453113
}

Submitted on 2 Feb 2017

HAL is a multi-disciplinary open access archive for the deposit and dissemination of scientific research documents, whether they are published or not. The documents may come from teaching and research institutions in France or abroad, or from public or private research centers.
L'archive ouverte pluridisciplinaire HAL, est destinée au dépôt et à la diffusion de documents scientifiques de niveau recherche, publiés ou non, émanant des établissements d'enseignement et de recherche français ou étrangers, des laboratoires publics ou privés. 
Background

$\checkmark$ Fundametal frequency (F0) at vowel offset \& onset higher for voiceless than for voiced consonants [1-3]

Relative fundamental frequency (RFF) used to assess vocal effort in patients with more effort for lower RFF [4-7]

\section{Purposes}

To explore RFF variations according to the voicing \& the manner contrasts

$\checkmark \ldots \&$ to the phonation types known to involve different levels of vocal effort

To provide data for normal speakers

\section{Hypotheses}

RFF values will be lower for voiced than for voiceless stops \& fricatives

- RFF values will be lower for high, loud \& pressed phonations (more vocal effort) than for low, soft \& breathy phonation (less vocal effort)

Methodology

$\checkmark 12$ normal French speakers (6 women \& 6 men)

$\checkmark 4$ consonants with voicing \& manner contrast

- 7 phonations types : spontaneous (baseline), low or high, soft or loud \& breathy or pressed

- Control of intra-speaker difference to baseline for pitch (FO), intensity (SLP) \& quality $(\mathrm{H} 1-\mathrm{H} 2)$

24 trains of 8 syllables, like "pafavabapafavaba"

For each, selection of the 4 central consonants

Measure of the relative fundamental frequency on the 10 cycles of the vowel offset $\&$ onset

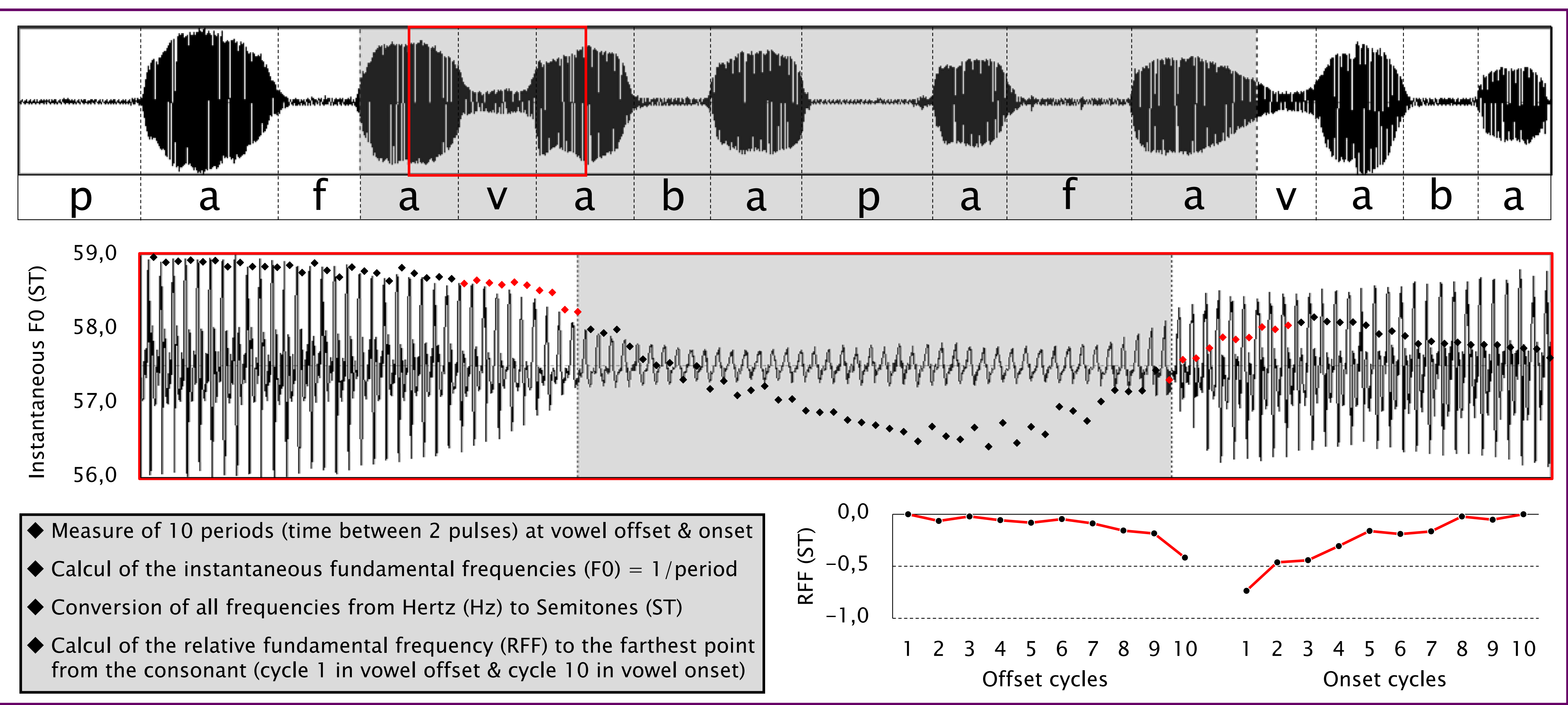

\section{Low-soft-breathy phonation}

\begin{tabular}{ccccc}
\hline & $\Delta \mathrm{F} 0(\mathrm{ST})$ & $\Delta \mathrm{SPL}(\mathrm{dB})$ & $\Delta \mathrm{H} 1-\mathrm{H} 2(\mathrm{~dB})$ \\
\hline Low & -3.5 & -0.4 & -0.1 & $\mathrm{n}=11$ \\
\hline Soft & -2.8 & -8.8 & +2.7 & $\mathrm{n}=11$ \\
\hline Breathy & -0.9 & -5.8 & +6.3 & $\mathrm{n}=9$ \\
\hline & -2.5 & -5.0 & +2.7 &
\end{tabular}

\section{V}

\section{b}
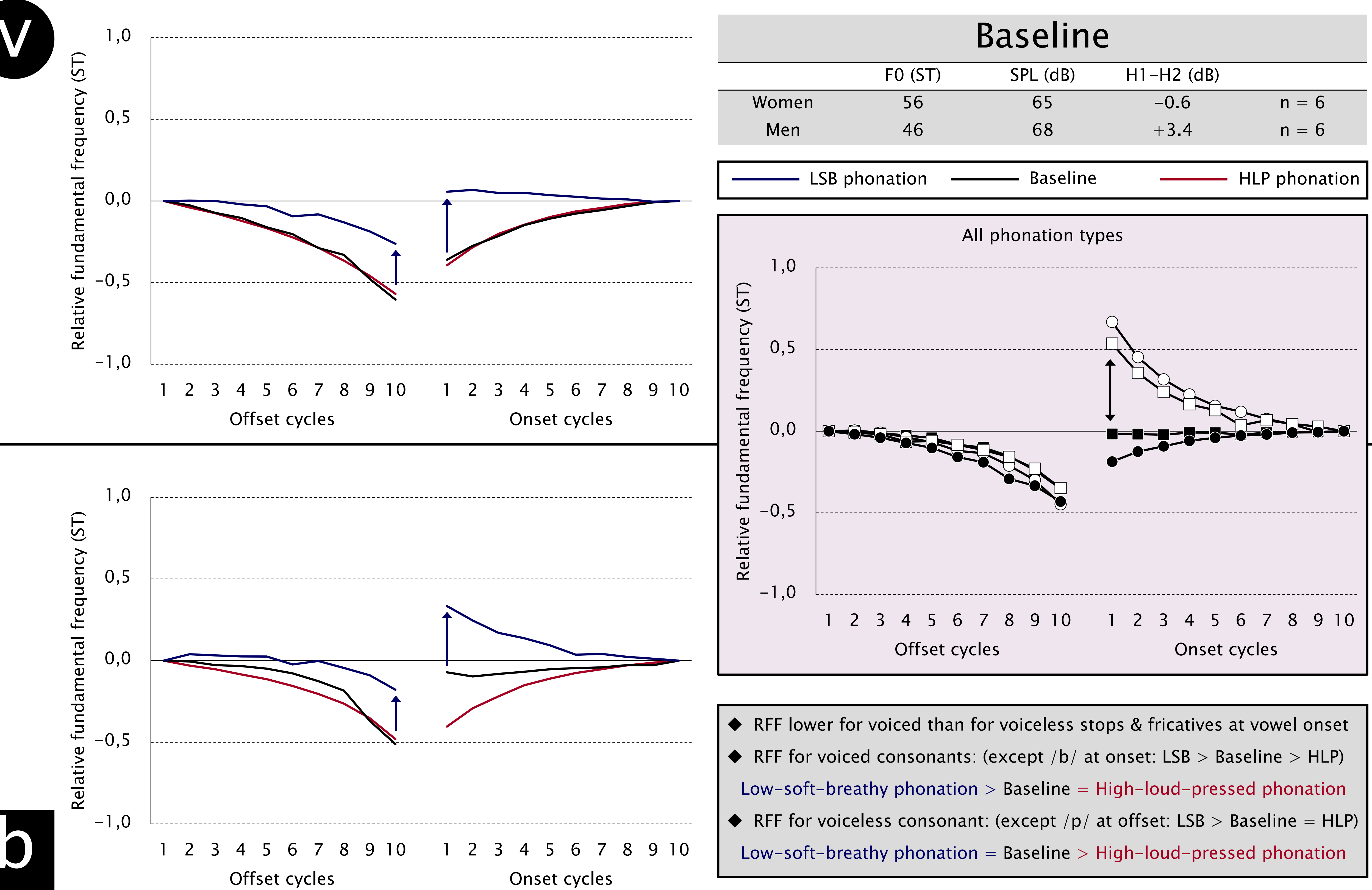

Discussion

$\checkmark$ RFF varies with vocal effort: higher RFF/lower effort in LSB phonation (+ voiceless consonants) \& lower RFF/higher effort in HLP phonation (+ voiced consonants)

- Possible to decrease but not to increase the vocal effort for voiced consonants \& possible to increase but not to decrease the vocal effort for voiceless consonants

$\Rightarrow$ In spontaneous phonation: production of voiced consonants at their maximum vocal effort but production of voiceless consonants at their minimum vocal effort
High-loud-pressed phonation

\begin{tabular}{ccccc}
\hline & $\Delta \mathrm{F} 0(\mathrm{ST})$ & $\Delta \mathrm{SPL}(\mathrm{dB})$ & $\Delta \mathrm{H} 1-\mathrm{H} 2(\mathrm{~dB})$ \\
\hline \multicolumn{1}{c}{ High } & +6.3 & +3.2 & -1.3 & $\mathrm{n}=9$ \\
\hline \begin{tabular}{c} 
Loud \\
\hline Pressed
\end{tabular} & +5.2 & +11.7 & -5.1 & $\mathrm{n}=10$ \\
\hline & +3.8 & +9.2 & -1.8 & $\mathrm{n}=7$ \\
\hline & +5.2 & +8.1 & -2.9 &
\end{tabular}

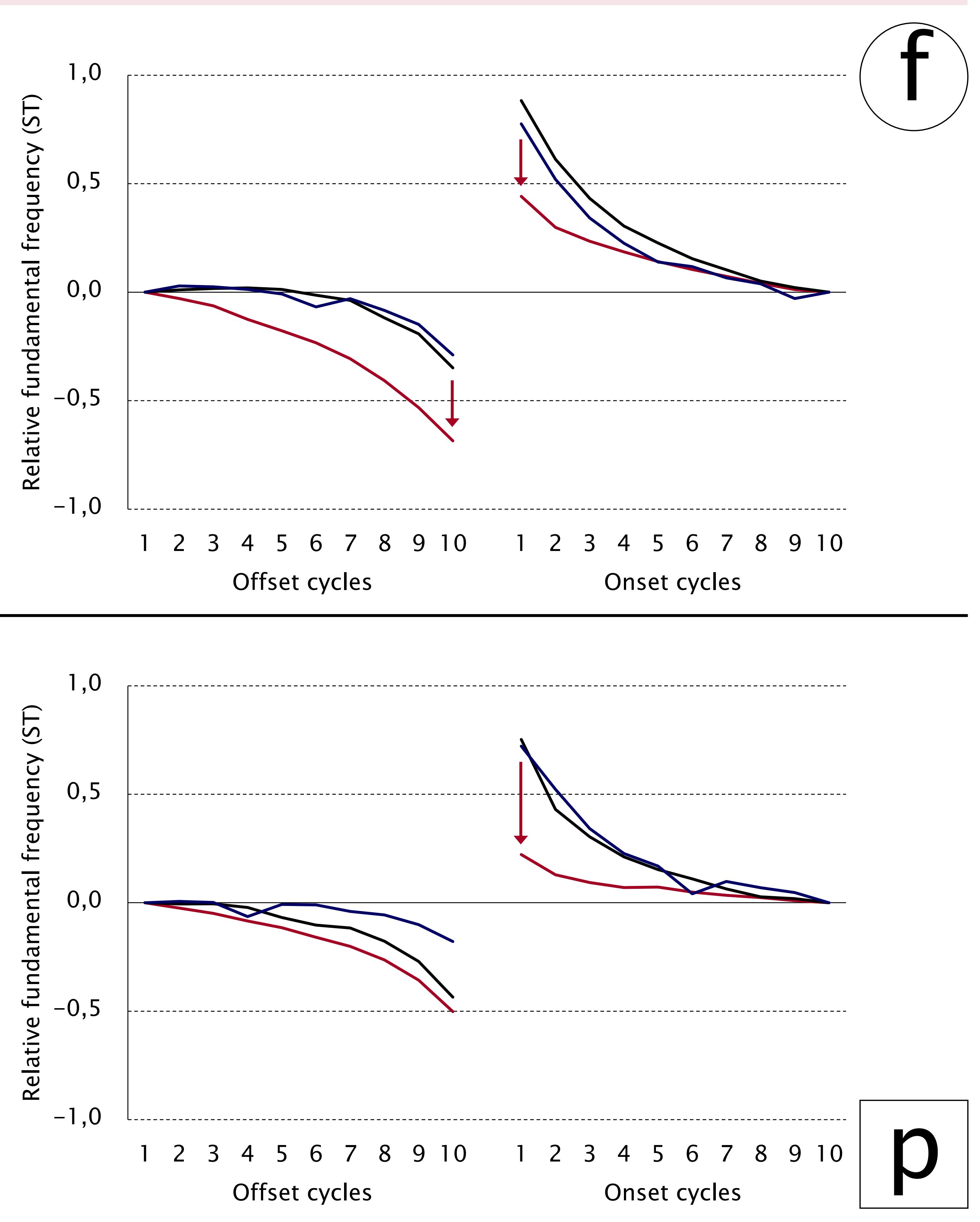

References

[1] Haggard M, Ambler S, Callow M. Pitch as a voicing cue. J Acoust Soc Am. 1970;47:613-7. [2] Löfqvist A, Baer T, McGarr NS, Seider Story R. The cricothyroid muscle in voicing control. J Acoust Soc Am. 1989;85:1314-21.

[3] Ohde RN. Fundamental
Soc Am. 1984; $75: 224-30$.

[4] Stepp CE, Hillman RE, Heaton JT. The impact of vocal hyperfunction on relative fundamental frequency during voicing offset and onset. J Speech Lang Hear Res. 2010;53(5):1220-6. [5] Stepp CE, Eadie TL. Relative fundamental frequency as a
spasmodic dysphonia. J Acoust Soc Am. 2011;129:2526.

[6] Stepp CE, Merchant GR, Heaton JT, Hillman RE. Effects of voice therapy o relative fundamental frequency during voicing offset and onset in patients with vocal hyperfunction. Speech Lang Hear Res. 2011;54(5):1260-6.

[7] Stepp CE, Sawin DE, Eadie TL. The relationship between perception of vocal effort and relative fundamental frequency during voicing offset and onset. I Speech Lang Hear Res. 